Est Ag 39 (2004) 135-168

\title{
Nietzsche, crítico y liberador del cristianismo: entre Diónisos y el Crucificado
}

\section{Introducción}

La obra de Nietzsche (1844-1900) es una crítica de toda la tradición occidental -metafísica, religiosa, moral, cultural-. Nietzsche creía que el hombre tenía que sostenerse sobre sus propios pies, ser ley de sí mismo, sin apoyo de la fe, ni de la razón, ni de la sociedad, ni de las tradiciones. Cada uno tiene que ser fiel por principio a su propia experiencia y a su propia historia ${ }^{1}$. Los criterios o razones para vivir, de cualquier tipo que sean, no le pueden venir al hombre impuestas desde fuera, sino que él las crea o las inventa, según sus deseos o apetencias. Cada persona debe seguir su propio camino, del mismo modo que las estrellas siguen su trayectoria. A esa luz hay que contemplar los grandes temas nietzscheanos, desde el nihilismo a su crítica del cristianismo, desde el eterno retorno a la propuesta utópica del superhombre.

Nietzsche comienza sus escritos juveniles sobre Grecia ${ }^{2}$, esa Grecia que ha sido y, en cierto modo, aún es hogar de sentido y figura tutelar de nuestra memoria espiritual europea, en cuya idea Nietzsche intentó introducir ciertos desplazamientos específicos capaces de modificar su sentido y su valor, a la vez que daba sus primeros pasos por el áspero camino de la crítica de la cultura moderna.

1. NiETzsche, F., Thus spoke Zarathustra. A book for everyone and no one, (=Penguin classics), Penguin, Baltimore-Maryland 1968, 42 y 44 . Zaratustra pide encarecidamente que permanezcamos fieles a la tierra y no creamos a quienes hablan de esperanzas sobreterrenales, ya que son envenenadoras. El profeta expresa admiración por aquellos que no buscan razones más allá de las estrellas para descender o sacrificarse, sino que más bien se inmolan ellos mismos a la tierra.

2. Sus primeros trabajos publicados en el Rheinischen Museum pertenecen a estudios sobre Teognis, Diógenes Laercio, Homero, etc. Su primer libro será El nacimiento de la tragedia o Grecia y el pesimismo (=Libro de bolsillo 456), Alianza editorial, Madrid 1988, 278 pp. 
Nietzsche era hijo de un pastor de la iglesia luterana. Su padre murió pronto y su madre quería que su hijo siguiese la tradición familiar y llegase a ser también ministro de la iglesia. Nietzsche no nació ateo. El ambiente familiar en que fue educado se caracterizaba por una religiosidad pietista ${ }^{3}$. Su personalidad humana se forjó en el seno de una larga tradición de pastores protestantes, donde cultivó un profundo sentimiento religioso ${ }^{4}$. Se cuenta que contando sólo seis años leía capítulos de la Biblia con tal dramatismo que sus compañeros le escuchaban conteniendo el aliento; le apodaron el "pequeño pastor"'5.

Fue educado en el más famoso de los internados protestantes en Alemania (Schulpforta) y lo primero que estudió al llegar a Bonn fue teología. Pero, apenas terminado el primer semestre, interrumpe el estudio de la teología y se dedica exclusivamente a la filología clásica ${ }^{6}$. Como veremos, su ataque al cristianismo no es objetivo, desinteresado, ni pacífico, sino violento, tiene mucho de drama; en palabras de J. M. Valverde se da un "combate cuerpo a cuerpo"7.

El ateísmo de Nietzsche, filósofo visceral y poeta, no fue el resultado de sus reflexiones filosóficas, sino el presupuesto instintivo de las mismas. Así lo dice en su obra autobiográfica $E c c e H_{o m o}{ }^{8}$. Vivirá el ateísmo como tarea a proclamar, anunciando el hundimiento del cristianismo y el advenimiento de una humanidad nueva, sin Dios ni moral. Su filosofía es un puro grito, una filosofía a martillazos 9 . De ahí que sea difícil evocar su filosofía. Su pensamiento se resiste a la objetividad y a los planteamientos desapasionados. Dios no puede vivir más en la conciencia de los hombres, es un huésped indeseable.

3. Ross, W., Friedrich Nietzsche. El águila angustiada. Una biografía (=Paidós testimonios), Paidós, Barcelona-Buenos Aires-México 1994, 267-268. Algo en lo que no se suele reparar es que éste aparentemente despiadado predicador del superhombre contrajo la difteria y la disentería cuidando a enfermos contagiosos durante la guerra franco-alemana (1870-1871).

4. Salaquarda, J., Nietzsche and the Judean-Christian tradition, en BERnd, M., and KatheleEn M. H., The Cambridge Companion to Nietzsche, 91-94.

5. Ross, W., Friedrich Nietzsche, 35-42.

6. SAFRAnSKI, R., Nietzsche. Biografía de su pensamiento (=Fábula 181), Tusquets, Barcelona 2002, 44.

7. VAlverde, J. M., Nietzsche de filólogo a anticristo, Planeta, Barcelona 1993, 266.

8. NiETZSCHE, F., Ecce Homo. How one becomes what one is, translated and introduction by R. J. Hollingdale, Penguin Books, New York 1985, 51.

9. No olvidemos que el subtítulo del Crepúsculo de los ídolos es: "cómo se filosofa con el martillo". 
Según Savater ${ }^{10}$ nos interesa Nietzsche porque sus teorías nos resultan "literalmente indigeribles". Leemos a Nietzsche porque "nos indigna", porque nos provoca. Lo esencial de Nietzche es la "blasfemia"; una blasfemia que va dirigida contra todo y contra todos, incluso contra él mismo. Nietzsche es una gran acusación contra los pilares de la modernidad: contra la identidad personal, el progreso y el sentido de la historia; contra las categorías gramaticales, la compasión, los derechos del hombre, el democratismo humanista y la razón científica.

Nietzsche dice que el mensaje de Jesús de Nazaret ha sido estropeado por san Pablo y que el cristianismo de Pablo no tiene casi nada que ver con el de Jesús de Nazaret11. El Crucificado de Pablo exalta la muerte contra la vida; Jesús, en cambio, quiso la vida sin ver la muerte. San Pablo es un tipo que usa Nietzsche, y concentra en su persona la crítica que dirige al cristianismo. Nietzsche acusa a Pablo de haberse inventado la historia del cristianismo primitivo, olvidándose de la verdad histórica, al hacerla descansar en la mentira del "resucitado". De este modo, desplazó el centro de gravedad de toda la vida de Jesús detrás de su existencia terrena. Pablo coloca el centro de gravedad de la vida no en la vida, sino en el más allá -en la nada- con lo cual la vida real se desautoriza o se degrada.

Pablo ha introducido el platonismo, el mundo supraterreno de las ideas, de las esencias eternas y verdaderas, contrapuesto al mundo terreno de las cosas, lo mudable y aparente. En la cima del mundo superior de las ideas está el Dios-Verdad. Tal supramundo de las ideas y los valores morales es irreal, está más allá de lo pensable y sensible, es puramente metafísico y, por eso, no se puede acceder a él de ningún modo. Este mundo ideal no es una realidad positiva, sino solamente negación de lo que es real: el mundo "aparente".

El origen de este supramundo está en la insatisfacción que el hombre experimenta en su mundo terreno, deseos frustrados, sufrimiento, cansancio, impotencia. La religión es así, la expresión de la decadencia del hombre, de la cobardía de su espíritu. Nietzsche señala que la idea de Dios surge del sentimiento de la propia fuerza, de la conciencia del poder que hay en él o del amor que le envuelve, pero que el hombre experimenta como no proveniente de sí mismo, sino de algo ajeno y superior a él, es decir, divino. El hombre

10. SAVATER, F., Idea de Nietzsche, Ariel, Barcelona 1996.

11. Nietzsche, F., El Anticristo. Maldición sobre el cristianismo (=Libro de bolsillo 507), Alianza editorial, Madrid 8 1981, (42) 73. "A la "buena nueva" la sucedió inmediatamente la peor de todas: la de Pablo. En Pablo cobra cuerpo el tipo antitético del "buen mensajero", el genio en el odio, en la visión del odio, en la implacable lógica del odio. ¡Cuántas cosas ha sacrificado al odio este disevangelista!". 
no se atreve a atribuirse a sí mismo este poder o este amor y los hace atributos de un ser sobrehumano que le es extraño. Reparte en dos esferas los dos aspectos de su propia naturaleza. La religión, por eso, es una alteración de la personalidad. En este punto se aprecia la influencia de Feuerbach.

Nietzsche presenta un pensamiento fragmentario ${ }^{12}$, inacabado, conciso, zigzagueante, sinuoso, pero profundamente coherente, que trata de liberar al ser humano de la concepción totalitaria en la que le había encerrado la filosofía occidental anterior, incluida la ilustrada. Su metodología se caracteriza por la sospecha total. Desconfía por principio de todo lo precedente, cualquiera fuera el grado de consenso en torno a una idea. Pone en duda todo, incluso lo que pudiera parecer obvio y evidente, y lo que hasta entonces consideraban válido todos los filósofos.

\section{La tradición occidental}

La cultura occidental se construye sobre la base de Atenas y Jerusalén. La tradición religiosa y sacerdotal impregna todo el pensamiento. El cristianismo (Jerusalén), que se puede definir como fe en la verdad, es también fe en la razón, es decir, ha usado la filosofía griega para expresar el mensaje cristiano.

El pensamiento occidental es la búsqueda de fundamentos absolutos, que no existen o que sólo existen en el mundo de las ideas y que son generadores del dogmatismo y del fanatismo religioso, político y filosófico. Nietzsche intenta desenmascarar esta tradición que es el resultado del entretejimiento inicial y ulterior desarrollo de tres factores: la ratio socrática, el platonismo y el cristianismo.

El hombre europeo es conformado como hombre teorético, como contemplador de la vida. El hombre asume ante su propia vida la actitud de espectador y se forma su propia "representación" -obviamente "teoréti-

12. Ross, W., Friedrich Nietzsche, $53^{8}$. Nietzsche utiliza para escribir generalmente aforismos. Este modo de escribir puede estar marcado por las limitaciones de una enfermedad que no le permite un trabajo sistemático y una concentración continuada. No obstante, algún libro, como por ejemplo, La genealogía de la moral sí que tiene una estructura sistemática. SAFRANSKI, R., Nietzsche, 168, considera que los aforismos no han de tergiversarse como una obra fragmentaria, sino que quieren anunciar también que el tiempo, por lo menos el tiempo del autor, no está maduro todavía para la obra cerrada, sistemática. NiETZSCHE, F., Crepúsculo de los ídolos o cómo se filosofa con el martillo (=Libro de bolsillo 467), Alianza editorial, Madrid 2 1975, 128. El mismo Nietzsche dice que es el maestro entre los alemanes en el aforismo, ya que es capaz de decir en diez frases lo que todos los demás dicen en un libro. 
ca"- sobre lo que ocurre ante su vista: desde las condiciones vitales básicas hasta el destino mismo, que pasa así a constituirse en objeto de contemplación para un sujeto. Nietzsche descubre en el origen del pensamiento griego lo teorético junto con lo trágico y va a contraponer el hombre teorético al hombre trágico. Esta dualidad se expresa también en los dos aspectos profundos del alma griega, lo apolíneo y lo dionisíaco. Según Nietzsche, la tragedia, que nos pone en contacto con la vida primigenia, reivindica lo dionisíaco ${ }^{13}$, en cambio, lo apolíneo representa una visión racional del mundo y se centra en la idea y en la verdad, con lo que, en cierto modo, reduce la vida a razón y a conceptos ${ }^{14}$. Con la muerte de la tragedia se dará primacía al espíritu apolíneo y va a triunfar el socratismo y la filosofía.

Frente a esto, Nietzsche trata de hacernos caer en la cuenta de que la esencia de la cultura griega es la captación de esta dimensión trágica de la vida. El decir sí a la vida incluso en sus problemas más extraños y duros. Éste es el hecho fundamental de la cultura griega y del instinto helénico, que se expresa claramente en los misterios dionisíacos ${ }^{15}$. El predominio de lo racional, por el contrario, es un acto de cobardía, de miedo a lo que la existencia tiene de extraño y terrible: éste es el significado del socratismo, platonismo y de la cultura moderna. Tratan siempre de tranquilizar y todo lo reducen a la armonía, el equilibrio, la medida, y así olvidan la otra cara de la vida: el dolor de la existencia, la muerte y las crueldades de todo tipo.

En el pensamiento occidental la verdad, lo verdadero, no son las cosas tal como aparecen o como hay que habérselas con ellas en la vida; al con-

13. El arte trágico es el producto más original de la rivalidad helénica entre Apolo y Diónisos, entre la medida y la desmesura. En palabras de Nietzsche: "la tragedia es el coro dionisíaco que se descarga en el mundo apolíneo de imágenes" (El nacimiento de la tragedia, (8) 84). No obstante, para Nietzsche el verdadero protagonista de la tragedia es Diónisos, pero Diónisos habla el lenguaje de Apolo.

14. NiETZSCHE, F., El nacimiento de tragedia, (12)108-111. Nietzsche presenta a Sócrates como prototipo de hombre teórico contrapuesto al hombre trágico. Sócrates se opone a Diónisos de la misma manera que el saber filosófico se opone al saber trágico. En Sócrates predomina la lógica, la racionalidad intelectual, es incapaz de ver la vida que fluye a su alrededor. Sócrates es el primer gran decadente, pues opone la idea a la vida, presenta la vida como si debiese ser juzgada por la razón, se vende a la verdad y a los conceptos, olvidándose de la vida. En ese Sócrates se encarna el principio del saber y de la verdad, dirigido contra la tragedia. Nietzsche reivindica y trata de recuperar la verdadera cultura griega, la que se llama arcaica y tiene una continuidad en la tragedia.

15. Nietzsche, F., Crepúsculo, 134. En la psicología del estado dionisíaco se expresa el hecho fundamental de la cultura griega, la "voluntad de vida". Por medio de estos misterios el heleno se garantizaba la vida eterna, el eterno retorno de la vida, el sí triunfante dicho a la vida por encima de la muerte y del cambio. La vida verdadera como supervivencia colectiva mediante la procreación, mediante los misterios de la sexualidad. 
trario, en el camino hacia esa presunta verdad, debe acometerse el intento de tomar distancia respecto de las cosas de la vida inmediata. Sencillamente porque las cosas no son tal como a primera vista se nos presentan, sino lo que sobre ellas puede decirse en una teoría coherente. Esta sobrevaloración del acceso lógico o teorético a lo verdadero significa, a la vez, una minusvaloración que, pensada hasta el final, lleva, en cualquier caso, a la depreciación de la vida y a la negación de este mundo nuestro en nombre de un mundo suprasensible o "mundo verdadero", constituido por múltiples formas o ideas, que se convierten en valores muy superiores a la vida real.

No hay verdad y falsedad sino en la medida en que hay bien y mal; es decir, lo siempre-estable, lo siempre-idéntico (el mundo de las ideas de Platón), no sólo es la verdad sino el bien. Justamente algo es verdadero porque es bueno. Así, el conocimiento de la verdad aporta la salvación, nos entrega el bien en que consiste ese mundo trascendente que está más allá del devenir, es decir, más allá del sufrimiento. Pero esto quiere decir: más allá de toda vida, en la nada. Por ello los ideales morales conducen a la muerte, a la autodestrucción, al anonadamiento.

Este sistema da lugar a dos mundos diferentes como los que afirmaba Platón, uno bueno y real -el de las ideas- y otro malo e ilusorio -el de la materia caótica-. Lo malo existe desde siempre igual que lo bueno, según la filosofía griega, o bien, como en el cristianismo, es el resultado de una culpa original. Y curiosamente, este mundo terreno, que tiene una existencia aparente, es la sede de lo malo, del sufrimiento, de la finitud, y por lo tanto, es demonizado. En cambio, todo lo bueno, verdadero y bello, que tiene un origen divino y está separado de lo terreno, es lo que debe buscarse.

En esta presentación del mundo late ya, para Nietzsche, tanto en el aspecto del conocimiento como en lo práctico-moral, el "nihilismo europeo". Un nihilismo que consiste en decir que algo es, en verdad, distinto de cómo se nos ofrece de modo inmediato. El nihilismo surge, pues, en un principio como depreciación de la inmediatez de la vida. Radica sumariamente, en decir que lo que es, no es lo que parece ser en el tráfico normal de la vida, sino lo que la correspondiente explicación científico-natural-matemáticaideal, nos dice.

El pensamiento occidental es un acto de odio contra la vida. Para Nietzsche todo el pensamiento occidental es platonismo ${ }^{16}$, es decir, dualis-

16. NiETzSCHE, F., Crepúsculo, 131-132. Nietzsche reivindica a los sofistas frente al platonismo, como por ejemplo a Tucídides, y el Renacimiento, entre otros, a Maquiavelo. Nietzsche hace una apuesta por lo real, no por la razón, lo ideal, o lo que debería ser la 
mo. Pero si analizamos qué es el dualismo hallaremos su elemento esencial en la afirmación de la existencia de un más allá. Esta afirmación contiene una negación oculta que hay que desentrañar. "Creo en un más allá" significa "no creo que este mundo sea lo único y que yo vaya a desaparecer para siempre". Creer así es negar la vida como finitud y, por tanto, la muerte. Ahora bien, como "la vida en este mundo" es lo único real, si se la niega, se acaba con todo lo que existe y se afirma otro mundo, que es pura fantasía, es decir, la nada. Por eso la cultura occidental es nihilista, cree en el más allá, es decir, en algo que es "nada".

En la medida en que para Nietzsche la actitud teórica descansa sobre una ficción, la de un acceso temporal y libre de destino a las "verdades eternas", toma cuerpo la pregunta por la verdad de la actitud teorética misma. En su relación con los otros el hombre que piensa de acuerdo con estos cánones "europeos" se hace asimismo una imagen general del hombre tal como éste debe ser. Es decir, vive su vida moral desde lo que debería ser y presenta una imagen general "humanista" del hombre, cómo debe ser el hombre, individualmente tomado, y cómo debe comportarse "humanamente".

Por último, apuntar otro rasgo del pensamiento europeo: la tendencia a la simplificación. En la medida que es un pensamiento que tiende a explicar, el pensamiento del hombre europeo es un pensamiento simplificador. Toda explicación es, en efecto, una simplificación. Con la consecuencia, por parte de este pensamiento, de su desgarramiento respecto del carácter multicolor y de la diversidad de la vida.

\section{La muerte de Dios}

Nietzsche dirige su crítica de la religión al núcleo de ésta, es decir, a la misma idea de Dios y a su contenido ilusorio. Se trata de una crítica frontal que aparece muy pronto en su pensamiento. En sus escritos de juventud, desenmascara al Dios arbitrario que castiga al ser humano y lo hace sufrir sin motivo, un Dios moralizador al servicio del orden moral. Dios y moral son una misma cosa. La filosofía va de la mano de la incredulidad y desemboca en la ausencia de toda moral.

La expresión "muerte de Dios" no es original de él, la había utilizado ya Hegel inspirándose en Lutero. Nietzsche, hijo y nieto de pastores pro-

moral. La cultura sofista es la cultura de los realistas y la propia del instinto griego. Frente a esta cultura apareció el pensamiento de Platón, la cultura ideal, que no es otra cosa que miedo a lo real; por eso se construye un mundo ideal. 
testantes, conocía la expresión "Dios mismo ha muerto" y la habría cantado repetidas veces, como también lo habría leído en Hegel. Expresiones similares son utilizadas por algunos místicos como Eckhart, Böhme, Silesius. Con la afirmación "Dios ha muerto" se hace referencia a la dimensión trágica de la religión cristiana, todo lo contrario de la religión superficial y edulcorada del "alma bella", que sólo busca tranquilizar conciencias.

Aunque no sea original suya, Nietzsche convierte la expresión "muerte de Dios" en categoría central de su filosofía y le da un sentido distinto al que tenía en los autores citados anteriormente ${ }^{17}$.

La parábola de la muerte de Dios se encuentra en el número 125 de $L a$ Gaya Ciencia cargada de patetismo y tragedia. “¿Dónde está Dios? ... Nosotros lo hemos matado... ¿Cómo hemos podido hacer esto? ¿Cómo pudimos vaciar el mar?... ¿Quién nos ha dado la esponja para borrar el horizonte entero?... ¿Qué hemos hecho cuando hemos separado esta tierra de la cadena de su sol?... ¿No será que caemos sin cesar hacia abajo, hacia atrás, hacia un lado, hacia todos los lados?... ¿Y que hemos perdido el centro de gravedad porque no existe ya para nosotros el arriba y el abajo?...". El mar simboliza la infinitud, este inmenso espacio en el que hay que saber embarcarse, ahora que toda la tierra está cubierta de sombras.

La expresión "Dios ha muerto" es el centro de su filosofía. Esto no quiere decir que haya estado vivo en el pasado, sino que proclama o anuncia un acontecimiento histórico irreversible de la fe ateística en la humanidad actual, para la cual el Dios-verdad, el Dios-moral del cristianismo no cuenta nada porque no es sino una nada divinizada por el hombre. Nietzsche reconoce que aunque Dios era una invención humana, en lo principal, había sido un hito histórico, que irradiaba gran poder y que había creado dos mil años de historia de la humanidad a su imagen y semejanza.

La parábola nos presenta a un loco, que puede ser el portavoz, quien en pleno día con una linterna, recordándonos a Diógenes, busca a Dios, pero va a la plaza pública y se dirige a incrédulos, los que ya no creen en Dios. Este loco quiere persuadir a los hombres a ser consecuentes con su ateísmo escondido; les dice: "Nosotros lo hemos matado: vosotros y yo", es decir,

17. Ross, W., Friedrich Nietzsche, 569 y 579 ss. Hemos de reconocer que Nietzsche se muestra especialmente angustiado por la muerte, que le ronda. La muerte de su padre a los 36 años ejerce una acción opresora en su vida, cree que puede repetirse en su vida. Piensa que la muerte le puede agarrar en cualquier momento. Repite la frase de Lutero media vita in morte sumus, a mitad de la vida estamos rodeados de muerte. Después de superar los 36 años encontrará gusto por la vida y parece que se libera un poco de la obsesión por la muerte. Aunque la enfermedad que le cerca se lo recordara constantemente. Véase también Ecce Homo, 38-39. 
pide a los hombres una decisión existencial de una fe totalmente ateísta. La muerte de Dios es algo querido por él y por todos e incluso anima a eliminar la sombra de Dios-muerto pues es un residuo peligroso. Nietzsche reconoce que se necesitarán siglos para que la sombra de Dios desaparezca de la masa de los humanos.

El loco es el que pone el dedo en la llaga y dice verdades que nadie se atreve a decir. Nietzsche no se inventa el acontecimiento de la muerte de Dios. Estaba en el ambiente. Los tiempos no eran propicios para la fe en Dios. El clima intelectual estaba teñido de ateísmo tanto en el terreno filosófico como en el científico. Sin embargo, la fe en Dios seguía viva. Había miedo a proclamar el ateísmo.

En medio de este clima, lo que hace Nietzsche es dar la noticia de la muerte de Dios, ayudar a caer en la cuenta de la importancia del fenómeno, que califica como "el más grande de los acontecimientos recientes", y a tomar conciencia de las gravísimas consecuencias. ¿Por qué? Porque la fe en Dios había conformado hasta entonces Europa y había sido la base espiritual de su cultura. "La muerte de Dios comienza a proyectar sus primeras sombras sobre Europa" (La Gaya Ciencia, 343). Desaparecida esa base, la cultura europea se veía amenazada y corría el peligro de desmoronarse.

Nietzsche prevé que su proclamación de la "muerte de Dios" suscitará en la gente común el sentimiento de precipitarse en una "nada infinita", en el vacío y oscuridad totales; el mar infinito está abierto... "Por fin el horizonte se nos presenta libre... finalmente pueden zarpar de nuevo nuestras naves a pesar de todos los peligros. Toda audacia está de nuevo permitida; el mar, nuestro mar, está otra vez abierto, quizá no ha habido un mar tan abierto" (La Gaya Ciencia, 343). En la fe ateísta el hombre recupera la libertad pero se siente con miedo ante este nuevo horizonte. Con la fe ateísta tiene lugar la liberación del hombre: surge una historia nueva de la humanidad, una historia más gloriosa que cualquier historia del pasado. La noticia sobre la muerte del viejo Dios hace sentir a los filósofos, los espíritus libres, como seres iluminados por un nuevo amanecer; nuestro corazón rebosa de gratitud, asombro, presentimientos, esperanza. Finalmente, se nos vuelve a aparecer el horizonte despejado.

La filosofía concibió a Dios como un teórico "puro" de este tipo, situado más allá de toda subjetividad y de todas las concepciones relativas de los humanos y capaz, a la vez, de penetrar con su mirada en el corazón y en la raíz (o causa) de los afectos. Dios fue, pues, concebido por los filósofos como absolutización del esquema gramatical básico de la teoría y de la posi- 
ción del espectador no participante. Éste es el Dios contra el que Nietzsche se dirige y cuya muerte anuncia ${ }^{18}$. Un Dios pensado como causa de todas las cosas, esto es, como prolongación del esquema de nuestras explicaciones y simplificaciones, en las que reducimos todo a "casos idénticos" y a leyes. Un Dios, en fin, que siendo el resultado de la absolutización de un esquema, lo es de la "fe", si se prefiere, en la gramática de nuestro pensamiento como forma de una verdad absoluta. La "muerte de Dios" importa en cuanto es el indicio de un hundimiento del recurso a un sentido pre-establecido y el signo precursor de una nueva posibilidad para la libertad de crearse por fin a sí misma sin requisitos previos.

La "muerte de Dios" significa que el concepto de Dios en el que éste es pensado como la posición teorética absoluta más allá de la vida, el "conocimiento" de Dios así afirmado, lo es en y desde el nihilismo. Sólo que, si en el caso del esquema de la representación teorética o de la ontología moral el conocimiento desenmascarador de su condición de esquema condicionado y específico no hace, por sí mismo, posible ya su eliminación, aquí lo único que queda, en principio, superado es "el Dios moral". Las exigencias morales dejan de valer, en efecto, tan pronto como deja de creerse en el carácter absoluto de su pretensión. Ahora bien, por mucho que Nietzsche hable de la muerte de Dios, no nos desembarazaremos de Dios mientras sigamos creyendo en la gramática, como él mismo nos advierte ${ }^{19}$. El nihilismo es descrito, así, como la "fe" insuperable en un Dios ya muerto, como una fe no superable a voluntad, en fin, en una "filosofía común de la gramática", que opera más allá de las propias diferencias de contenidos cosmovisionales.

A la fe atea le seguirá el nihilismo. El Dios cristiano ha sido durante veinte siglos el sentido y el fin de la humanidad y del mundo, y el resultado de su muerte no puede ser sino la ausencia de sentido, el vacío. El nihilismo tiene dos sentidos: La desaparición del supramundo ideal y la aceptación del vacío que surge de la destrucción de ese idealismo. El nihilismo es la nada y la aceptación de la nada. No hay respuesta al "por qué" ni al "para qué": nada es verdadero, todo está permitido.

Se necesita fuerza para vivir en un mundo sin Dios, sin moral, sin sentido "más allá del bien y del mal". Con la muerte de Dios el ser humano recupera su libertad y su creatividad, y se torna autosuficiente. Nietzsche des-

18. NieTzsche, F., Thus Spoke Zarathustra, 68. Nietzsche creería sólo en un Dios que supiera danzar.

19. NieTzsche, F., Crepúsculo, 59. 
cribe el camino hacia la plena libertad a través de bellas y expresivas imágenes.

La primera es la que habla de las tres transformaciones del espíritu en camello, del camello en león y del león en niño ${ }^{20}$. La transformación del espíritu en camello se caracteriza por el sometimiento a la ley moral, que obliga al ser humano a cargar con fardos pesados por la obediencia a Dios. Con la transformación del camello en león, el ser humano logra la libertad de: se libera de los preceptos morales, de las leyes, de la voluntad divina. La persona hace un acto de afirmación de la voluntad: "yo quiero". La transformación del león en niño es la metamorfosis suprema, que lleva a la libertad positiva, a la libertad para, que se traduce en la búsqueda de alternativas, creatividad y sentido lúdico. El ser humano conquista su mundo y quiere su voluntad. Esta transformación requiere un nuevo nacimiento con los dolores de parto propios de quien lo engendra. Hay que pasar del "tú debes" (moral del camello) anterior al "yo quiero" (moral del león) de la responsabilidad propia, sin normas externas; $y$, a través de éste, se llega a la plenitud del "yo soy", propio de la inocencia del niño, sin interferencias externas, como estando dentro de la nada, la existencia sin más, sin reflexión, en la pura espontaneidad.

Nietzsche rechaza sobre todo el Dios de la moral que impone desde fuera leyes y sanciones. Para sobrevivir a la muerte de Dios y al nihilismo será necesario transformar al hombre que hemos conocido hasta ahora. Deberá surgir el hombre del futuro, el superhombre, "vencedor de Dios y de la nada", que puede renunciar a todas las esperanzas supratemporales. Su existencia será meramente facticidad en la fidelidad a la tierra, sin trascendencia. "Han muerto todos los dioses: ahora queremos que viva el superhombre"21. Como no hay dioses la humanidad debe avanzar, debe ascender y ocupar el lugar de los dioses; por eso está obligada a ser creativa.

\section{La crítica del cristianismo}

Nietzsche parte de la complejidad del hecho religioso; nos dice que el estudio de los hombres religiosos es una "caza mayor" y exige recorrer bosques inmensos inexplorados ${ }^{22}$, pero parece que pronto olvida este punto de

20. NiETZSCHE, F., Thus spoke Zarathustra, 54-56.

21. Ibid., 104.

22. NieTzsche, F., Más allá del bien y del mal. Preludio de una filosofía de futuro (=Libro de bolsillo 406), Alianza editorial, Madrid 1972, (45) 71-72. 
partida, pues no es nada prudente cuando habla del cristianismo; ya que se deja llevar por una actitud pasional y conflictiva, como inmediatamente veremos.

El cristianismo, en cuanto "platonismo para el pueblo" 23 , cae en el veredicto nietzscheano de nihilismo, en la medida en que en él y con él se institucionaliza y difunde el pensamiento moral. El platonismo significa la negación del mundo real en nombre de un mundo verdadero de las ideas, en nombre de un deber ser que él mismo representa y que, en cuanto máscara e instrumento a un tiempo de la voluntad de poder, está en sus propios orígenes.

La crítica del cristianismo y la crítica de la modernidad ${ }^{24}$ son una misma cosa, ya que ésta ha asumido los valores del cristianismo. Incluso los ilustrados, que combatieron la idea de Dios, aceptaron la moral cristiana. También ellos predicaron el amor al prójimo, la compasión, la lucha contra los malos instintos, la humildad, el respeto al deber, la justicia, la igualdad, etc.

Nietzsche en $\mathrm{El}$ Anticristo arremete duramente contra el cristianismo. Lo acusa de luchar contra los instintos fundamentales, de tomar partido por lo débil, lo bajo y malogrado, de negar la vida, de impulsar la decadencia de la especie. Nietzsche concluye diciendo que es indecente ser cristiano.

El punto central de la crítica al cristianismo es que va en contra de la vida $^{25}$, y es una religión decadente. Dios se presenta como enemigo de la vida y, por lo tanto, si queremos afirmar la vida, tenemos que negar al enemigo de la vida. Es la misma crítica que ha hecho de la moral, pues va también en contra de la vida. Nietzsche presentará una nueva moral, regida por el instinto de vida ${ }^{26}$. La vida y la voluntad de vivir o de poder que en ella se

23. NiETZSCHE, F., Más allá del bien, 19.

24. Nietzsche también critica la modernidad por haber asumido una moral decadente. La democracia era para él una forma decadente de Estado; la igualdad por la que había luchado Europa era el "final de la justicia". Nietzsche insiste en que somos desiguales y nadie debe pretender igualarnos (SAFRANSKI, R., Nietzsche, 76). Nietzsche considera que un Estado democrático con su orientación al bienestar general, a la dignidad humana, la libertad, la justicia distributiva y la protección de los débiles, impide la posibilidad de desarrollo de grandes personalidades.

25. NiETzSCHE, F., Crepúsculo, 54: "Pero atacar las pasiones en su raíz significa atacar la vida en su raíz: la praxis de la Iglesia es hostil a la vida..." NiETZSCHE, F., Crepúsculo, 57: "Casi toda la moral hasta ahora enseñada, venerada y predicada se dirige, por el contrario, precisamente contra los instintos de la vida."

26. NiETZSCHE, F., El Anticristo, (18) 43: "Dios como Dios de los enfermos, Dios como araña, Dios como espíritu es uno de los conceptos de Dios más corruptos que se ha llegado en la tierra; tal vez represente incluso el nivel más bajo en la evolución descendente del tipo de los dioses... ¡En Dios, declaraba la hostilidad a la vida, a la naturaleza, a la voluntad de vida!". 
muestra, es el fundamento de los valores. En cada valor se despliega una voluntad de poder. Así, los hay que brotan de una vida rebosante, y otros, que nacen de la miseria, de la debilidad.

Nietzsche critica la religión judeo-cristiana, que por su práctica y valoración antivitales, promueve una actitud negativa frente a la vida. El cristianismo ha desplazado el centro de gravedad; ya no se ocupa de la vida, sino del más allá, que es como decir la nada ${ }^{27}$. El cristianismo ha estado tan preocupado por la inmortalidad individual que muchas veces ha despreciado y olvidado el más acá, la vida, precisamente lo único importante. La concepción de la vida después de la muerte ha servido, históricamente, para despreciar la vida concreta. Al poner la perfección en otro mundo, los hombres han despreciado éste. Los cristianos en vez de luchar por llegar a ser perfectos aquí y ahora, han puesto su esperanza en un futuro lejano ${ }^{28}$.

En cambio, en el Evangelio, en la vida de Jesucristo, no se observa nada de esto. Al contrario, Jesús es el hombre pegado a la tierra que trata de ayudar a que la vida sea mejor: consuela, perdona, cura a los enfermos, se acerca a los desarrapados. Precisamente, la religión cristiana es una religión de vida y no de muerte, y el Dios cristiano es un Dios de vivos y no de muertos. Ahora bien, hay que reconocer que en determinadas épocas y ambientes, se ha dado mucha importancia a la muerte y la religión cristiana ha estado centrada en la muerte; y los cristianos, más que resucitados, hemos parecido sepultureros 29 .

La crítica al Dios cristiano viene porque impide que los hombres se desarrollen, que lleguen a su plena autonomía, ya que viven dependiendo de alguien que está fuera del mundo. Dios viene a ser para ellos el sustituto de todo aquello a lo que el hombre se agarra como tabla de salvación ante los problemas de la vida. Como Dios es el "no" a la vida, el cristianismo es una religión nihilista, contraria a la vida; pues expresa resentimiento contra la vida ${ }^{30}$.

27. Nietzsche, F., El Anticristo, (43) 74-75: "Cuándo se coloca el centro de gravedad de la vida no en la vida sino en el "más allá" - en la nada- se le ha quitado a la vida como tal el centro de gravedad... El cristianismo es una rebelión de todo lo que -se arrastra- por el suelo contra lo que tiene altura: el Evangelio de los "viles" envilece...".

28. Kaufmann, W., Nietzsche.Philosopher, Psychologist, Antichrist, Princeton University Press, Princeton ${ }^{4}$, New Jersey 1974, 346.

29. NiETzSCHE, F., Thus spoke Zarathustra, 116. Nietzsche reprocha a los cristianos no parecer redimidos, sino vivir aherrojados en cadenas. Los cristianos tendrían que aparecer como enamorados y testigos de la vida nueva, reflejar en su vida la gloria y el gozo de la salvación de Dios.

30. NietzsCHe, F., El Anticristo, (47) 82-83. "Ha sido venerado como Dios... para nosotros es un crimen contra la vida. Nosotros negamos a Dios en cuanto Dios... Si se nos 
Desde la ilustración, esta presentación de Dios es difícilmente aceptable, sería un Dios "tapaagujeros", un Dios para impotentes, para personas que no han llegado a la mayoría de edad. La autonomía del hombre y su capacidad para resolver los problemas estaría prácticamente anulada, sería un Dios que impediría al hombre realizarse como tal, alcanzar su propia autonomía, un Dios que impediría al hombre ser hombre.

El cristianismo afirma la vida eterna y feliz y, con ello, demuestra ser una forma de hedonismo, es decir, una doctrina que promueve la búsqueda del placer como sentido de la vida, pero de un placer que se reserva para después de la muerte. Nietzsche recuerda que la fe cristiana esconde el deseo de que las cosas sean como nosotros quisiéramos, de acuerdo con nuestros más profundos deseos. Pero esta salvación cristiana es ilusoria, en realidad produce lo contrario de lo que anuncia: al pedir entrega, sacrificio, condenar la sexualidad, la corporalidad... lo que promueve es la muerte. El mundo eterno, inmutable que se promete es, en realidad, el silencioso reino de la nada. El cristiano no puede soportar la vida tal como es, con su sufrimiento y falta de sentido, y entonces ha de huir hacia un más allá que no existe. El secreto oculto del cristianismo es el odio a la existencia sensible y real, en virtud de una hipotética otra vida. El cristianismo representa la venganza del débil, de los que quieren la nada porque la vida nunca podría ser querida por ellos: se les hace sumamente dura.

Para Nietzsche la interpretación moral ${ }^{31}$ convierte el mundo en algo propiamente "insoportable". El cristianismo, con esta interpretación moral, ha intentado superar el mundo, vencerlo, reconciliando al tiempo al hombre consigo mismo y con el mundo. Con el odioso resultado de haber llevado finalmente al hombre al "empequeñecimiento", al "empobrecimiento". Sólo la más mediocre e insignificante especie de hombre, la de los hombres del rebaño, encontró ahí su honra, sólo ella fue impulsada y pudo, al precio de una ficción y un "no", sentirse reforzada. Esta ha sido una historia en la

demostrase ese Dios de los cristianos, sabríamos creerlo menos aún. Dicho en una fórmula: deus qualem Paulus creavit, dei negatio. Una religión del cristianismo, que en ningún punto tiene contacto con la realidad...". Véase también El Anticristo, (52) 91: "Si tuviéramos en el cuerpo cierta cantidad, aunque fuera muy pequeña, de piedad, un Dios que nos cura a tiempo del resfriado o que nos hace subir al coche en el preciso instante en que se desencadena un aguacero, debería ser para nosotros un Dios tan absurdo, que aunque existiese, habría que eliminarlo. Un Dios como criado, como cartero, como calendario, en el fondo, una palabra para designar la especie más estúpida de todas las causalidades".

31. SAFRANSKI, R., Nietzsche, 194-197. Para Nietzsche la historia de la moral no es moral, y en los sentimientos morales no se mueve lo bueno en el hombre, sino que se aprecia en ella toda una larga historia de costumbres e inculcaciones culturales. 
que lo que finalmente se ha expresado es una voluntad de poder "mediante la que, bien los esclavos y oprimidos, bien los fracasados y atormentados por ser como son, bien los mediocres, han hecho el intento de imponer los juicios de valor más favorables para ellos".

De ahí que Nietzsche hable de dos tipos de moral, la moral de los señores que sigue ideales nobles y la moral de los esclavos (impotentes, degradados) que sigue ideales plebeyos. El criterio de tener o no tener resentimiento es el que permite distinguir entre una moral de los señores y una moral de los esclavos. El resentimiento es una expresión de debilidad e impotencia. Nietzsche está en contra del resentimiento, porque es una emoción amarga y repugnante que los fuertes no pueden sentir; sólo los débiles se alimentan de ella. El resentimiento es una emoción que no promueve la excelencia personal, sino que reside en una estrategia competitiva para destruir o amenazar a otros. El esclavo está siempre condicionado por lo exterior que le debilita, exterioridad a la cual se opone y niega como modo de obtener una cierta valía y aprecio de sí mismo. Este autoaprecio procede, pues, de una negación y oposición. El juicio de los débiles es: "Tú eres malo, yo soy bueno". Su bondad nace de la reacción negadora, del debilitamiento del fuerte. Ellos actúan siempre a la contra. El juicio de la moral aristocrática, de toda moral afirmativa, es juntamente el contrario: "Yo soy bueno, tú eres malo". Primero está la afirmación y después la negación nacida de aquélla. El "tú eres malo" no es más que algo que se desprende de una serena y triunfal afirmación de sí mismo.

Es precisamente de esta moral de esclavos de dónde arranca el cristianismo y toda la moral cristiana. La psicología del cristianismo nace del espíritu de resentimiento de los débiles. La fe cristiana es un refugio para los débiles, y la moral cristiana es una moral de los débiles y esclavos. Entonces el resentimiento se hace creativo y genera valores que condenan todo aquello que los fuertes consideraban bueno ${ }^{32}$. La nueva moral es el producto de una rebelión de los esclavos, una reacción defensiva frente a la moral de los nobles. Esta moral no busca la excelencia y la perfección en uno mismo, sino que surge de un prejuicio defensivo frente a aquellos que son capaces de conseguir la felicidad, que los débiles no pueden alcanzar. El resentido sólo es capaz de valorar negando y desvalorizando. El resentido odia la fuerza del otro y busca su venganza en desposeerle de ella, no para disfru-

32. Nietzsche, F., La Genealogía de la moral. Un escrito polémico (=Libro Bolsillo 356), Alianza editorial, Madrid 4 1979, I (10), 42-43. 
tar de ella, sino para impedir su goce por los demás. El resentido reproduce en su vida el colmo de la venganza y de la envidia ${ }^{33}$.

Los débiles no toleran la virtud de los fuertes ya que les recuerda su propia mediocridad, todo en la vida les hace daño y les resulta excesivo; entonces acumulan odio y resentimiento contra los que viven valientemente. Este odio se dirige contra los fuertes con el fin de rebajarlos y evitar el agravio comparativo. El arma utilizada para conseguirlo es la ética altruis$\mathrm{ta}^{34}$. Por medio de ella se pide al hombre excelente que se sacrifique, que sea humilde y se reprima. Así vence el resentimiento y el fuerte es igual al débil. El cristianismo es heredero de esta transvaloración moral realizada por los judíos, de la rebelión de los esclavos en la moral. El cristianismo no es la religión del amor, sino la del odio contra los buenos, los nobles, poderosos; pues defiende la bondad de los débiles y cansados de la vida.

En esta critica al altruismo, Nietzsche no es nada original, sino que sigue el ejemplo de otros filósofos, como Platón, Aristóteles o Kant. Todos ellos sitúan la propia perfección y la excelencia como la meta de la moralidad. Aunque al igual que los griegos, Nietzsche considera que la propia perfección se consigue mejor en compañía de los amigos. Zaratustra, por ejemplo, no invita a amar al prójimo, sino a los amigos 35 .

Nietzsche afirma que el amor cristiano y la idea de igualdad de los hombres $^{36}$ tiene su origen en el rencor reconcentrado de los débiles, que no quieren resignarse a las relaciones existentes del poder y se sienten incapaces de cambiarlas: el resentimiento es "el odio reprimido de los débiles" 37. Los ideales de bondad, humildad, de amor a los enemigos y de justicia en la

33. NIETZSCHE, F., Aurora. Reflexiones sobre los prejuicios morales. Traducción de Genoveva Dieterich, Alba, Madrid 1999, (304), 243: “¡Como yo no puedo tener algo, el mundo entero no ha de tener nada, el mundo entero no ha de ser nada!".

34. NieTzSCHE, F., Crepúsculo, 108-109. Nietzsche critica la moral altruista pues lleva a no valorar la vida personal; de hecho pone el centro en motivos desinteresados, olvidándose de sí mismo. Nietzsche hace una crítica al altruismo en Aurora (131-148) 130-149.

35. NieTzSCHE, F., Thus Spoke Zaratustra, 87-88.

36. Nietzsche, F., Más allá del bien, (202-203) 133-137. Nietzsche considera el movimiento democrático no como una forma de decadencia de la organización política, sino como una forma de decadencia total, esto es, del empequeñecimiento del hombre. Esto lleva a la degeneración global del hombre al convertirlo en un animal de rebaño, un animal enano dotado de igualdad de derechos y exigencias. Véase también Crepúsculo, 115-116.

37. Nietzsche, F., La Genealogía, I (10) 43. La moral noble nace de un triunfante sí dicho a sí mismo, impregnado de vida y de pasión; la moral de los esclavos, por el contrario, dice no. Esta inversión de la mirada que establece valores es fruto del resentimiento. La moral de los esclavos nace siempre por oposición a un modelo externo al que se opone, su acción es reacción. 
tierra son fabricados en el taller de los incapaces de una acción victoriosa, es decir, de los débiles ${ }^{38}$.

El cristiano es, en efecto, para Nietzsche "el animal doméstico, el animal de rebaño, el animal enfermo hombre", exactamente lo contrario, por tanto, de ese tipo superior, digno de vivir y seguro del futuro, erguido sobre la tierra con el gran "sí" en los labios, que él mismo considera como "el más valioso". El cristianismo ha hecho una guerra a muerte a este tipo superior de hombre, ha proscrito todos los instintos fundamentales ${ }^{39}$. Al prohibirse el placer (que no son capaces de obtener), al despreciar el cuerpo ${ }^{40}$ y cultivar lo negativo (el odio a la vida), el débil se hace cada vez más resentido. Este resentimiento se manifiesta en la creación de una moral llena de prohibiciones y limitaciones al disfrute. Ello es debido a que los débiles no soportan que otros sí puedan disfrutar de la vida mientras para ellos sólo significa dolor. La sexualidad 41 y la agresividad de los "fuertes" son reprimidas.

El veredicto final nietzscheano del cristianismo como "religión de la compasión ${ }^{42 " ~ y ~ c a l d o ~ d e ~ c u l t i v o ~ d e ~ l o s ~ v a l o r e s ~ n i h i l i s t a s, ~ d e ~ l o s ~ v a l o r e s ~ d e ~}$ decadencia, encuentra aquí su lógica profunda. De ahí la vinculación profunda que Nietzsche establece entre cristianismo y nihilismo. Porque la compasión, ese rasgo central del cristiano, no es, desde este prisma, sino la

38. NiETZSCHE, F., Crepúsculo, 113: "Nuestras virtudes están condicionadas, vienen provocadas por nuestra debilidad... La "igualdad", un cierto asemejamiento efectivo, que en la teoría de la "igualdad de derechos" no hace otra cosa que expresarse, es parte esencial de la decadencia: el abismo entre unos hombres y otros, entre unos estamentos y otros...".

39. NiETZsCHE, F., El Anticristo, (5) 29-30: "El cristianismo ha tomado partido por todo lo débil, bajo, malogrado, ha hecho un ideal de la contradicción a los instintos de conservación de la vida fuerte; ha corrompido la razón incluso de las naturalezas dotadas de máxima fortaleza espiritual al enseñar a sentir como pecaminosos, como tentaciones, los valores supremos de la espiritualidad." NiETzSCHE, F., Más allá del bien, 89. Nietzsche acusa al cristianismo de poner cabeza abajo todas las valoraciones y quebrantar a los fuertes, debilitar las grandes esperanzas, pervertir todo lo soberano, varonil, conquistador, en definitiva, todos los instintos. Transformando todos esos sentimientos vitales en inseguridad, tormento de conciencia, autodestrucción, más aún, han dado la vuelta a todo el amor a lo terreno y al dominio de la tierra, convirtiéndolo en odio contra la tierra y lo terreno.

40. NiETzsche, F., Crepúsculo, 125: "El cristianismo, que ha despreciado el cuerpo, ha sido hasta ahora la más grande desgracia de la humanidad".

41. NiETzSCHE, F., Crepúsculo, 135: "Sólo el cristianismo, que se basa en el resentimiento contra la vida, ha hecho de la sexualidad algo impuro: ha arrojado basura sobre el comienzo, sobre el presupuesto de nuestra vida".

42. Nietzsche, F., El Anticristo, (7) 31-32. "Al cristianismo se le llama religión de la compasión... Uno pierde fuerza cuando compadece... en toda moral aristocrática se considera a la compasión una debilidad... la compasión es la praxis del nihilismo... Dicho una vez más: este instinto depresivo y contagioso obstaculiza aquellos instintos que tienden a la conservación y a la elevación del valor de la vida...". 
praxis del nihilismo, un instinto depresivo y contagioso que "obstaculiza aquellos instintos que tienden a la conservación y a la elevación del valor de la vida"; un instinto bajo que "tanto como multiplicador de la miseria cuanto como conservador de todo lo miserable es un instrumento capital para la intensificación de la décadence". Y de ahí también que el sacerdote sea considerado, en el contexto nihilista-cristiano, como una especie superior de hombre, cuando en realidad no es, siempre según el veredicto nietzscheano, sino un "negador, calumniador, envenenador profesional de la vida". Se trata de un proceso que es el del paso mismo del mago al sacerdote. Si el primero ejecuta el ademán auroral de dominio de un cosmos al que -como luego hará mucho más eficazmente el científico-impone leyes, el segundo se centrará ya en otra imposición, la de "leyes morales" del comportamiento físico, y su bondad nace de la reacción negadora, del debilitamiento del fuerte. Ellos actúan siempre a la contra. Un comportamiento cuyo dominio requerirá también por tanto, un complejo arsenal de técnicas: castidad, ayuno, disciplina de los sentidos, confesión, penitencia.

Los textos contra la compasión son duros y abundantes. La compasión es antitética de los efectos tonificantes que elevan la energía del sentimiento vital: produce un efecto depresivo. Uno pierde fuerza cuando compadece. La compasión es mala tanto para quien la ejerce, como para quien es compadecido. La compasión, en cuanto sentimiento ${ }^{43}$, no ayuda a los compadecidos hacia la felicidad, la perfección y el bienestar. Dedicándonos a la compasión, o haciendo obras de caridad nos apartamos de nuestro propio camino que es demasiado duro y exigente, nos escapamos de nuestra conciencia individual para refugiarnos en la conciencia de los demás ${ }^{44}$. La compasión no es desinteresada, toda nuestra conducta es egoísta y no podemos cambiarlo. La compasión, sin embargo, es nuestro mal amor hacia nosotros mismos, mientras que el amor por el amigo y hacia nuestra propia perfección ${ }^{45}$ es un amor superior. Con la compasión aumenta y se multiplica más aún la merma de fuerza que ya el padecer aporta en sí a la vida. Para

43. Nietzsche entendería la compasión como sentimiento de lástima o el simple compadecerse que no se queda más que en eso. Por lo que este ataque no va contra el sentido profundo de la compasión cristiana, que te hace ser consciente de los males y sufrimientos del mundo y de la gente, te lleva a sentirte cercano a ellos y te hace luchar para eliminarlos, como se puede ver claramente en la parábola del buen samaritano.

44. NieTZSCHE, F., La Gaya ciencia, Sarpe, Madrid 1984, (338) 164.

45. KaufManN, W., Nietzsche, 371. Nosotros tenemos que concentrarnos primero en nuestra propia perfección y el autoconocimiento; ésta es nuestra principal tarea. Por eso, correr a ayudar a otros es una debilidad psicológicamente hablando: dar limosna a otros es más fácil que esforzarse por conocerse y mejorarse a uno mismo. 
Nietzsche todo lo que procede de la debilidad es malo y decadente. Apostó siempre por lo que nunca tuvo: por la fuerza, la alegría, el humor, la salud y la plenitud desbordante ${ }^{46}$. El padecer mismo se vuelve contagioso mediante el compadecer. Uno nunca compadece a quien admira.

El cristianismo es el sacrificio de toda libertad, se convierte en una religión de esclavos y no de hombres libres. La persona fuerte no se apoya en la compasión, sólo la persona débil necesita apoyarse en algo externo a ella, sea lo que sea; compasión, normas, leyes, etc. Nietzsche soñó con una clase de hombres que no se mintiese a sí misma y se elevase por encima de las servidumbres sociales. Parece que aspiraba a una especie de hombre completo, libre y soberano. Deseaba la superación de lo conocido y que el futuro primase sobre el pasado.

Nietzsche pretende decirnos que la vida es el único valor y la única fuente de valor, y por lo tanto, que tenemos que tomar todos nuestros valores de ella. Tenemos que aceptar la vida, decir "sí" a una vida en plenitud, apostar por la vida. Debemos obtener todos los criterios, incluso los de racionalidad y verdad, de la vida misma. Lo que no favorezca la vida debe rechazarse como algo falso.

Nietzsche desenmascara también la idea de amor ${ }^{47}$. Zaratustra repudia el amor al prójimo pues es sólo un mal amor a sí mismo. Nietzsche no ataca el espíritu del sermón del monte, sino la moral filistea, es decir, la moral de

46. Nietzsche llegó a escribir frases: "Los débiles y malogrados deben perecer: artículo primero de nuestro amor a los hombres. Y, además, se debe ayudarlos a perecer." Es conocido lo que nazis y fascistas hicieron de estas proclamas. La interpretación fascista nietzscheana había sido iniciada por la hermana del filósofo, Elisabeth, que se casó con un antisemita muy activo, Bernhard Förster. Los mejores intérpretes de Nietzsche, Colli y Montanori, rechazan esta interpretación. En los textos aducidos ven el ataque de Nietzsche a la moral idealista. El autor de Zaratustra se propuso desenmascarar la ausencia de virilidad y la hipocresía disimuladas bajo la sensiblería humanitaria. Quiso poner al descubierto la mentira de la vida burguesa; se propuso hostigar la beatitud de rebaño de los profesores de moral de su época. Nietzsche rechazó los valores proclamados por el fascismo (fuerza militar, patria, nacionalismo, antisemitismo, pangermanismo). Además Nietzsche manifestó su simpatía por los judíos contemporáneos. Véase Más allá del bien, (251) 205207 y su abierta crítica a los antisemitas de su época; postura extraña y poco frecuente en la Alemania de su tiempo. Tampoco hay que olvidar que afrontó la mayor ruptura de su vida; la de su amistad con Wagner, porque éste defendía el pangermanismo, el antisemitismo y un cristianismo decadente.

47. KaufmanN, W., Nietzsche, 371. Nietzsche ataca una idea de amor que no corresponde con el ideal cristiano. Lo que él ataca es el resentimiento que frecuentemente se esconde detrás de la respetable fachada de la virtud cristiana. Ser bondadoso cuando se es demasiado débil y tímido para actuar de otro modo, ser humilde cuando actuar de otro modo tendría malas repercusiones. 
los hombres vulgares o débiles. El amor generalmente es egoísta, pues es muy frecuente que las personas inmaduras, aquellas que no saben estar solas, mediante el amor al prójimo lo que hacen es huir de sí mismas y, lo que es peor, quieren hacer de ello una virtud. El amor puede ser fructífero para las dos personas si intentan perfeccionarse a sí mismas; por eso, según Nietzsche, la relación más alta posible entre los seres humanos es el amor de amistad.

El amor puede ser simple codicia, un amor a sí mismo, tratar de poseer o dominar al amado. En la misma acción caritativa, uno lo que hace es buscarse a sí mismo. En el fondo, cuando amamos pensamos en nosotros mismos; nuestros actos de caridad muchas veces son interesados, un pretexto para sentirnos bien; muchos actos de amor sólo reflejan orgullo48. "Nuestro amor al prójimo, ¿no es ansia de nueva propiedad?... Ante un hombre que sufre, aprovechamos de buen grado la oportunidad ofrecida de tomar posesión de él; esto es lo que hace por ejemplo el caritativo y compasivo, también él llama "amor" al ansia de nueva posesión que en él se ha despertado" (La Gaya Ciencia, 14). El amor sexual es el mayor deseo de propiedad, un deseo de poseer.

Nietzsche reconoce y afirma la animalidad como la esencia del hombre; ese es el pensamiento grave, decisivo... y eso que podemos llamar pathos dionisíaco, es lo contrario de la compasión cristiana. Combatiendo el cristianismo ${ }^{49}$ combatía la falsa religión, la religión racionalista, antropocéntrica, que concedió al hombre una posición aislada en el mundo, y para poder hacerlo renegó la animalidad en el hombre.

48. Aurora (133) “...En el fondo, pensamos mucho más en nosotros mismos que en los demás, al observar las resoluciones que adoptamos en aquellos casos en que no podemos evitar el espectáculo que ofrecen los que padecen y gimen en la miseria... Al realizar actos de caridad, lo que hacemos es librarnos de ese padecimiento personal nuestro... queremos librarnos de un dolor, también lo es que cedemos a un impulso de júbilo, júbilo provocado por el espectáculo de una situación opuesta a la nuestra... Todo esto, y cosas más sutiles todavía forman la caridad". También Aurora (344): "El hombre caritativo satisface una necesidad de su alma haciendo el bien. Cuanto mayor sea esta necesidad, menos se pone en el lugar de aquel a quien socorre y al que sirve para satisfacer dicha necesidad, y hasta resulta duro y ofensivo en algunos casos".

49. El hombre es cuanto "desea"; es la bestia más absurda porque aspira a valores e ideales que no puede alcanzar y así introduce en su existencia la contradicción interior insuperable. Con la aceptación de una forma ética de la vida, ratifica su disociación incurable de sí mismo: se siente siempre despojado de su propio ser y siempre intentando superarse hacia el proyecto vacío de sí mismo. Nietzsche espera que una vez liberada la humanidad por la muerte de Dios, la existencia humana llegará a una plena coincidencia consigo misma en la inocencia autosuficiente. 
En la $2^{\mathrm{a}}$ parte de la Genealogía de la moral presenta los presupuestos básicos de la conciencia, o mejor dicho, de la mala conciencia. Nietzsche ve en el hombre el rasgo de animalidad. La crueldad existe en el hombre y no lo podemos olvidar diciendo que todos somos buenos y que podemos vivir la existencia edulcorada del "alma bella". La crueldad forma parte de la esencia del hombre, es como un instinto básico, el placer de ver el sufrimiento y el placer de hacer sufrir ${ }^{50}$. La crueldad es un trasfondo oculto de la cultura humana. La crueldad atraviesa toda la historia de la cultura; sin crueldad no hay fiesta. Así lo enseña la más antigua, la más larga historia del hombre. El hombre es siempre bestia: o hacia fuera, por medio de las pulsiones externas que crean la violencia, o hacia dentro, en el automartirio de la conciencia moral, con la culpa o creación de la mala conciencia 51 .

La fuerza constructora de estados es la misma que, reorientada hacia el interior, crea la mala conciencia y construye ideales negativos. Se trata de la voluntad de poder que anteriormente se vertía hacia fuera como violencia conquistadora y que ahora, reprimida en el interior del individuo, se dirige contra él mismo. El hombre somete y reprime sus instintos e impulsos. Entonces éstos se desahogarán hacia dentro, la crueldad que antes el hombre vertía hacia fuera ahora la emplea consigo mismo: eso es la mala conciencia. Pero ésta adquiere toda su crueldad con la religión. También aquí se trata de una deuda pero, al ser una deuda adquirida con Dios, se convierte en impagable: el dolor se multiplica en el interior del ser humano.

La persona se divide en su interior en una parte que domina, un aspecto interior tiránico, crítico con uno mismo, "artista" en cuanto pretende dar forma a la parte animal e instintiva de uno mismo reprimiéndola y castigándola. Se escenifica en nuestro mundo interno un juicio en el que nos constituimos en agresores y agredidos y nos decimos "no", condenándonos y despreciándonos. El mundo interior nace de esta autoagresión sadomasoquista en que consiste la mala conciencia. De ella surgen los más bellos ideales éticos, que no son más que la expresión de una voluntad de humillarse y hacerse daño: los ideales del desinterés, autonegación, sacrificio de sí mismo. El placer que siente el desinteresado, el abnegado, el que se sacri-

50. NiETzSCHE, F., Más allá del bien, (229) 177. Esta crueldad no sólo surge de gozar ante el sufrimiento ajeno, sino que encuentra gozo en el propio sufrimiento.

51. Nietzsche, F., La Genealogía, II (6) 74-76 y II (16) 96-97. 
fica, pertenece a la crueldad52. Sólo un gusto en el propio maltrato explica esta perseverancia en la propia humillación, que siente el ser humano.

Nietzsche valora y ve en la filosofía ciertas experiencias ascéticas, pero aquí estos ideales no son envenenamiento de las fuentes de la vida, no son una posición contra la vida. Lo que los filósofos buscan en el ideal ascético es el mantener su independencia creativa y fecunda por encima de todo. En cambio, el ideal ascético del sacerdote es un recurso a la vida débil y enferma para seguir viviendo. El hombre ha colocado ideales en su vida que pertenecían al más allá; eran inventos de sacerdotes e ideales contrarios a la naturaleza. Ya vimos en la segunda parte de la Genealogía de la moral el primer aspecto de la mala conciencia: multiplicación del dolor por interiorización de los instintos. Ahora, en la tercera parte se descubre el segundo aspecto: interiorización del dolor por cambio de dirección del resentimiento, potenciando con los ideales ascéticos las fuerzas reactivas ${ }^{53}$.

Los ideales ascéticos imponen la renuncia a las pasiones. El portador de estos ideales es el sacerdote (real o simbólico). Él modifica la dirección del resentimiento ${ }^{54}$, convence al enfermo de que él mismo es culpable de su enfermedad, le consuela y propone ideales de renuncia. Si en un principio el resentimiento estaba dirigido hacia fuera, ahora lo estará hacia dentro: el sacerdote explica que el sufrimiento es causado por el propio pecado, somos culpables de nuestro propio padecer. El sacerdote reinterpreta la crueldad vuelta hacia adentro (la mala conciencia), y halla la causa del sufrimiento en la noción de "pecado": la causa del sufrimiento está dentro de ti, en una culpa; tu sufrimiento es un estado de pena por tu culpa. El enfermo, de este modo, se ha convertido en pecador. Su dolor es el castigo merecido. Tenemos razones para odiarnos. Estos han constituido el único tipo de ideal hasta ahora existente. Por ello, siempre que el hombre ha querido elevarse lo ha hecho contraponiéndose a sus instintos. Toda voluntad ha sido, hasta el presente, ascética, es decir, voluntad de autosacrificio. Mas al querer

52. NiETzSche, F., La Genealogía, II (18) 100: "Sólo la mala conciencia, sólo la voluntad de maltratarse a sí mismo proporciona el presupuesto para el valor de lo no-egoísta". Véase también Más allá del bien, 177.

53. NiETzSche, F, La Genealogía, III (28) 185-186. “...El ideal ascético: ese odio contra lo humano, más aún, contra lo animal, más aún, contra lo material, esa repugnancia ante los sentidos, ante la razón misma, el miedo a la felicidad y a la belleza, ese anhelo de apartarse de toda apariencia, cambio, devenir, muerte, deseo, anhelo mismo - ¡todo eso significa, atrevámonos a comprenderlo, una voluntad de la nada, una aversión contra la vida, un rechazo de los presupuestos más fundamentales de la vida, pero es, y no deja de ser, una voluntad!... Y repitiendo al final lo que dije al principio: el hombre prefiere querer la nada a no querer...".

54. NiETzsche, F., La Genealogía, III (15) 147. 
estos valores, la voluntad quería la nada, la nada del "más allá" por el que los hombres se esforzaban. Faltos de alternativa, la voluntad prefería querer la nada a no querer nada. Esta voluntad de la nada es una aversión contra la vida. Por eso, todo el proceso acaba en negativo, en pesimismo, en la tragedia del nihilismo.

El asceta es un virtuoso del decir no. Es un poderoso anti-Diónisos. En el asceta se encarna la vida como espíritu, como un espíritu que poda la vida. Nietzsche habla de esto con cierta admiración, pues se da cuenta de que él mismo, a pesar del sí dionisiaco, es más bien una naturaleza ascética ${ }^{55}$.

Nietzsche vislumbra en el cristianismo una religión nihilista en la que late oculta una moral reactiva, inspirada en última instancia por una moral decadente, que ha llegado al hombre europeo de modo poderoso y recurrente a los ideales ascéticos que, en definitiva, no son otra cosa que el intento que hace la vida débil para sobrevivir, impulsando lejos de sí cuanto la contraría. En la religión como tal, no descifra Nietzsche sino el conjunto de medios morbosos a que el hombre recurre para confortar su enfermedad. Si la religión encuentra su razón de ser, su fuerza genuina en el miedo, también es cierto que ese miedo nace en el momento mismo en el que el hombre se enfrenta -como subraya Nietzsche- a sí mismo y siente su incapacidad profunda para automanifestarse y afirmarse en un mundo hostil. Nietzsche acusa al cristianismo de no ser creador y de haber sumergido a la humanidad en la actitud negativa y reactiva, a lo que de suyo lleva la mala conciencia; oponiéndose a esto, propone romper las resistencias de esta voluntad negadora para ordenarla a la afirmación y la creación de su mundo a partir de uno mismo.

\section{Nietzsche: un camino hacia Dios}

Veamos ahora cómo Nietzsche, a pesar de ser un portavoz del ateísmo, también expresa cierto respecto por Jesucristo y por el cristianismo serio, e incluso, intentaremos buscar un posible camino hacia el Dios cristiano.

El hombre, por mucho que quiera o desee, dado que es finito, no puede llegar a pensar algo que esté por encima de la razón; es pedir algo imposible. El hombre, como ser pensante, no soporta ir más lejos o saltar por encima de sí mismo. Dios no parece ocupar un lugar en la finitud del pensar humano. En este espacio limitado no hay lugar para Dios. Y, si Dios no

55. SAFRANSKI, R., Nietzsche, 324. 
puede ser pensado en el más acá, en la caducidad del ahora, es impensable para el hombre. De este modo podemos decir que "muerte de Dios" quiere decir que no se puede pensar un Dios a la manera humana; ya que la capacidad humana de un hombre finito, nunca puede abarcar el infinito.

Al hablar de la muerte de Dios, del Dios crucificado, tal como exige la teología cristiana-luterana de la cruz, ponemos a un mismo nivel Dios y la muerte, Dios y la caducidad; quizás ésta sea la forma de pensar a Dios; pues es un nuevo Dios, un Dios cercano al hombre, que se encarna y llega incluso a la muerte. Nietzsche nos dice que esto fue un invento de Pablo56.

Nietzsche ataca también con virulencia a Lutero por ser un poco el continuador de esa teología de la cruz, y considera el luteranismo, iglesia cristiana en la que se había educado, el grupo más sucio dentro del cristianismo. En cambio, Nietzsche ensalza, por ejemplo, a Cesar Borgia, como prototipo del hombre fuerte, ya que representa los valores de la vida, los valores del Renacimiento. Esto fue precisamente lo que Lutero ${ }^{57}$ criticó, la corrupción del papado, pues se había llegado a identificar tanto con la sociedad de su tiempo que se había convertido en un poder temporal más y había olvidado el Evangelio.

El crucificado es el débil, el carente de poder, el que se expone al oprobio y a la muerte. Pablo y los cristianos entienden esto como Evangelio, "buena noticia", no como tristeza, angustia o desesperación. Y es, precisamente, desde esta situación de muerte desde dónde surge la vida, la resurrección. El crucificado, el impotente, aparece ahora como el poder vitalizador de Dios, es el que vive para siempre. Dios es el que da vida a los muertos. Dios resucita al crucificado, a quién a los ojos de los hombres había aparecido como un fracasado y un impotente. Dios, devolviéndole la vida, certifica y confirma que su vida y mensaje tienen sentido. La resurrección es el sí del Dios de Jesús a la vida y a la pretensión del mismo Jesús. La resurrección elimina la ambigüedad de su fracaso.

56. Nietzsche, F., El Anticristo, (47) 83: "El Dios que Pablo se inventó, un Dios que deshonra la sabiduría del mundo". Véase también (40) 70: "Sólo la muerte, esa muerte ignominiosa y no aguardada, sólo la cruz, la cual estaba en general reservada únicamente a la canaille (gentuza), sólo esa horrorosísima paradoja enfrentó a los discípulos con el auténtico enigma".

57. NieTzSChe, F., El Anticristo, 108: "Lutero vio la corrupción del papado, siendo así que precisamente lo contrario podía tocarse con las manos: ¡En la silla del papa no estaban ya sentados la vieja corrupción, el peccatum originale, el cristianismo! ¡Sino la vida! ¡Sino el triunfo de la vida! ¡Sino el gran sí a todas las cosas elevadas, bellas, temerarias!... Y Lutero restauró de nuevo la Iglesia: la atacó...". 
De la expresión paulina "Cristo murió por nuestros pecados", ha surgido la interpretación sacrificial de la muerte de Jesús. De ella deduce Nietzsche la conversión de toda la vida en vida "reactiva", abrumada por el peso de esta deuda-culpa para con la divinidad. Pienso que esta no es la interpretación correcta de la teología paulina, aunque en diversas épocas se haya dado, y no hay que negar tampoco que para la teología católica durante siglos el hecho central ha sido el "sacrificio" de Jesús en la cruz. Desde esta visión se desprecia la vida y se oprime al hombre bajo el peso de la culpa. Pero ésta no es la visión de Pablo. El hecho central para él, el ámbito desde el que contempla toda la realidad es el de la Resurrección, el de la nueva creación abierta en el Cristo resucitado. Sin la resurrección, la muerte de Jesús no hubiera significado nada; ya que simplemente significaba el fracaso y la vanidad de toda esperanza. El Crucificado pues, para ser algo y significar algo, sólo puede ser contemplado desde el Resucitado. La muerte, símbolo y compendio de las fuerzas reactivas dominadas y dirigidas por la voluntad de lo negativo, no tiene ya dominio sobre el hombre del Espíritu. La muerte de Jesús en Pablo no lleva a lo reactivo, a la pesadumbre por la deuda sino a la libertad y a la alegría, a la apropiación humana de todas las fuerzas.

Nietzsche considera la resurrección una ilusión, algo que ayuda a escapar de la realidad de la muerte, del trágico destino del hombre. Con esta crítica, Nietzsche reconoce que el dolor de nuestra existencia no tiene remedio, que de nada nos valen ilusiones y mentiras para alejarlo de nosotros.

La teología de la cruz paulina es la negación más perfecta de la divinización de la potencia que se quiere a sí misma. Nietzsche comprendió muy bien y agudamente que aquí se iniciaba una nueva comprensión de Dios y por eso atacó duramente a Pablo y a Lutero; ya que iban en contra de sus planteamientos. "Todo lo que sufre, todo lo que cuelga de la cruz, es divino...".

Esta identificación del pobre y de todo el que sufre con Dios da realce a la naturaleza humana. Dios es el que sufre o muere cuando el hombre es despreciado o asesinado. Dios sufre o es expoliado cuando son oprimidos y explotados los pobres. Por eso, el Evangelio es "buena noticia" para los pobres y marginados de nuestra sociedad. Buena noticia, pues no llama a la resignación, sino a hacer todo lo posible por eliminar las situaciones de injusticia, aquellas situaciones que siembran la muerte en nuestro mundo. El Evangelio cristiano es una llamada a tratar de sembrar vida o esparcir las semillas de la resurrección y de la vida dónde no hay más que muerte y dolor. Una llamada a tratar de poner paz, amor y vida, donde hay guerra, 
odio y muerte. En definitiva, sería todo lo contrario de lo que critica Nietzsche. El Dios de Jesucristo es, por encima de todo, el Dios de la vida, aquél que: "vino para que tengan vida y la tengan en abundancia..." (In 10,10). Jesús vino para que todos tengan vida, especialmente para llenar de esperanza y de vida a todos aquellos que viven una vida infrahumana.

La manifestación de Dios se da a los pobres, leprosos, despreciables, no a los nobles, ricos y poderosos. $\mathrm{Y}$ es, precisamente, en los pobres, dónde aparece la belleza, la dignidad; hay realmente belleza en lo caduco. Por eso, creo que Nietzsche no acertó mucho en este punto y, por tanto, no es muy legítima la reducción del cristianismo a un platonismo para el pueblo. Aunque se haya dado esa interpretación desencarnada, el cristianismo tiene, desde sus orígenes, una meta liberadora ${ }^{58}$ y ha estado presente a lo largo de la historia, si bien es verdad que también, en nombre de Dios y del Dios cristiano se han cometido crímenes, abusos, injusticias, es decir, acciones contrarias a ese Dios de la vida y del amor.

Nietzsche captó agudamente que, igual que el Dios de la metafísica era impensable, el de la cruz es increíble. La negación de Dios no sólo se da en el pensamiento, sino también en la caducidad; Dios no puede soportar lo caduco, no puede pasar por la muerte ${ }^{59}$.

Dios en la cruz es presentado por Nietzsche como una formula escandalosa; supone la transvaloración de todos los valores. Nietzsche en este punto se muestra prisionero de la metafísica, aunque va contra ella. Nietzsche no puede entender lo perecedero, lo caduco, unido a la debilidad y al sufrimiento. Quería pensar lo caduco sin dolor; por eso protesta contra un Dios sufriente como un atentado contra la vida. En esta polémica contra el Dios crucificado Nietzsche piensa la vida en su caducidad de un modo abstracto y metafísico. Quiere ver justificada la vida perecedera sólo en cuanto vitalidad. Quizás, como él intuyó, sea posible pensar un Dios más allá de la esencia suprema y la moral que denigra lo vital. Nietzsche quiere

58. Valverde, J. M., Nietzsche, 163-164: "La religión en general puede servir para tranquilizar a los descontentos en lo que hoy día se ha llamado "teología de la resignación" por contraposición a la "teología de la liberación", ese uso de la religión como "opio para el pueblo" que actualmente favorece el "nuevo orden" -centrado en Washington-, y al que tan militantemente ha contribuido el Vaticano".

59. Nietzsche, F., El Anticristo, (47) 82: "Dios en la cruz, ¿es que todavía no se entiende el terrible pensamiento que está detrás de ese símbolo? Todo lo que sufre, todo lo que pende de la cruz, es divino. Todos nosotros pendemos de la cruz, por consiguiente somos divinos... sólo nosotros somos divinos... El cristianismo fue una victoria, por causa suya pereció una mentalidad aristocrática. El cristianismo ha sido hasta ahora la máxima desgracia contra la humanidad. 
llevar al hombre a la cima del superhombre: justifica la vida perecedera sólo en la cima de su vitalidad. Dios en la cruz no solamente es la negación de todo pensamiento de un Dios arbitrario, sino justamente, de un modo positivo, un Dios que se enfrenta a la nada que se halla en toda caducidad.

Por tanto, Nietzsche señala un nuevo modo de entender a Dios, como el Dios del amor, el Dios de la vida, el Dios que lucha contra el mal, el dolor, la muerte y cualquier tipo de sufrimiento o miseria que hay en el mundo.

Nietzsche, a pesar de su tremenda polémica contra el cristianismo, insinúa un camino de acceder a Dios. El amor como última posibilidad de la vida $^{60}$. Nietzsche polemiza contra la Iglesia, y sobre todo contra Pablo y Lutero, pero guarda un cierto respeto hacia Jesús ${ }^{61}$ y los cristianos serios ${ }^{62}$, cuya buena noticia (noticia de salvación, que trae la salud, la vida), sólo la Iglesia convirtió en dysangelium.

Veamos, pues, el Dios aceptable para Nietzsche. Sería un Dios de la vida y del amor, el Dios que permite al hombre ser auténtico hombre. El Dios que plenifica la vida y ni atonta ni esclaviza a los hombres. Un Dios que permite que los hombres se desarrollen y vivan una vida plena, sin ningún tipo de ataduras.

Nietzsche considera que lo distintivo del cristianismo es la vida práctica, una vida tal como la vivió el que murió en la cruz. Esa vida es posible para ciertos hombres e incluso necesaria. El cristianismo auténtico, el originario, será posible en todos los tiempos ${ }^{63}$. Lo original del cristianismo no es una fe nueva, sino una práctica que se puede aplicar para todos los tiempos. Jesús nos enseñó cómo se ha de vivir; nos legó un modo de vivir, una práctica. Sólo una vida práctica, una vida tal como la vivió el que murió en la cruz, es cristiana.

60. Nietzsche, F., El Anticristo, (30) 59: “... conoce la buenaventura (el placer), el amor como única, como última posibilidad de vida... El miedo al dolor, incluso a lo infinitamente pequeño en el dolor. No puede acabar de otro modo que en una religión del amor".

61. Nietzsche, F., El Anticristo, (39) 69: "Ya la palabra cristianismo es un malentendido -en el fondo no ha habido más que un cristiano-, y este murió en la cruz... El evangelio murió en la cruz. Lo que a partir de este instante se llama "evangelio" era ya la antítesis de lo que él había vivido: una "mala nueva", un "disangelio".

62. Nietzsche, F., Ecce Homo, 48. KaufManN, W., Nietzsche, 364. Nietzsche no denuncia el cristianismo serio, sino el cristianismo hipócrita, es decir, aquellos que no son cristianos en la práctica aunque lo proclamen de palabra, o bien aquellos que superficialmente parecen cristianos en su práctica, pero cuya motivación y estado de conciencia no es esencialmente cristiano. 
Aquí Nietzsche se muestra paradójico. Precisamente lo que antes más ha criticado, la moral cristiana como moral de la compasión ${ }^{64}$, de la ternura, de la misericordia, y del amor; es ahora lo que ensalza como lo más original de Jesucristo ${ }^{65}$, lo que realmente vino a enseñar y lo que tiene que ser continuado por el cristianismo auténtico. Nietzsche protesta contra la degeneración de lo que originalmente era el cristianismo con tanta "cólera sagrada" como si él fuera cristiano 66 .

En los apuntes inéditos de unos meses antes de escribir El Anticristo (nov. 1887- marzo 1888) Cristo llega a parecer lo contrario del Dios "enemigo de la vida" a quien tantas veces se ha enfrentado. Nietzsche cree encontrar en el proyecto de Jesús lo que el mismo busca: una vida idéntica consigo misma, la reclamación para el hombre de los atributos extinguidos en Dios. La vida de amor como paradigma de la virtud. Se podría afirmar, dado el ateísmo de Nietzsche, el sentido inverso de la frase bíblica: el amor es Dios.

Tengamos en cuenta que Nietzsche, al igual que el ateísmo moderno, no afirma simplemente la no-existencia de Dios, sino que rechaza más bien a un Dios concreto, represivo frente al hombre y la vida, por atribuir los predicados divinos al hombre.

Por eso, si somos capaces de extraer del Evangelio y del mensaje de Jesús, y por qué no, también de la misma tradición cristiana, un Dios que está a favor de la vida, que potencia la vida, que da al hombre una vida plena, entonces seguramente Nietzsche no rechazaría ese Dios. Pues, como hemos visto, la mayor acusación contra el Dios cristiano es ser "enemigo de la vida".

Si concebimos a la divinidad de Dios unida a lo caduco, la existencia del crucificado, entonces a Dios ya no se le puede pensar como infinito en contraposición con lo finito, ni como esencia suprema que no conoce la nada,

64. SAFRANSKI, R., Nietzsche, 177 y 331. Nietzsche impugnó la moral de la compasión, pero, en contra de sus deseos, era un genio del corazón y el ser compasivo perteneció sin duda a su primera naturaleza, a sus instintos. El Dios cristiano de la compasión siguió siendo un punzón en la carne. Por más que Dios esté muerto en la conciencia pública, no obstante, Nietzsche notó su repercusión en la moral de la compasión.

65. NieTzsche, F., El Anticristo, (16) 41. "Un mojigato, timorato, modesto, que aconseja "la paz del alma", el no-odiar-más, la indulgencia, incluso el "amor" al amigo y al enemigo. Ese Dios moraliza constantemente, penetra a rastras en la caverna de toda virtud privada, se convierte en un Dios para todo el mundo...".

66. Nietzsche, F., El Anticristo, (36) 66: "Que la humanidad esté postrada de rodillas ante la antítesis de lo que fue el origen, el sentido, el derecho del evangelio, que haya canonizado en el concepto "iglesia" justo aquello que el "buen mensajero" sentida por debajo de sí, por detrás de sí -en vano se buscará una forma mayor de ironía histórico-universal-". 
sino que Dios se acerca a lo finito, a lo perecedero. En lugar del Dios que está en el cielo, porque no puede estar en la tierra, se nos presenta a un Padre-Dios, que está en el cielo de tal manera que su cielo celeste puede venir al mundo perfectamente, es decir, un Dios que está en el cielo y, por eso mismo, puede identificarse con el hombre. En la existencia de Jesús de Nazaret vemos cómo Dios se acerca al hombre, se identifica con los problemas cotidianos, e incluso con el hombre llevado a la cruz.

La muerte de Dios es la indicación más original de Dios para el amor. En la cruz de Jesús, Dios es definido como amor, Dios es amor (1 Jn. 4,8). En el acontecimiento especial de la identificación de Dios con el crucificado se manifiesta Dios como aquél que es ya desde siempre en sí mismo.

Con esta presentación, vemos que el cristianismo no es algo decadente, no va contra la vida, no chupa sangre ni odia a todo aquello que se yergue con grandeza. El cristianismo, de este modo, no se caracteriza por la corrupción de las almas, por el concepto de culpa, el castigo y la inmortalidad. La fe en la inmortalidad no es para desvalorizar la vida en nuestro mundo. $Y$ creer en la "resurrección" significa creer en la vida, en una vida nueva para el hombre, la historia y el cosmos. La resurrección es una afirmación sobre las posibilidades humanas, es el triunfo de la vida sobre la muerte. Es decir, todo lo contrario de una descalificación y desprecio de la vida terrena. La liberación ya no pasa por el reconocimiento de que la vida no vale nada, ni por la mortificación del cuerpo, sino que se intenta una liberación por el sentido del compromiso con el mundo y con los problemas de los hombres.

\section{Zaratustra, el hombre comprometido con la vida}

Nietzsche no sólo es un crítico y maestro de sospecha, sino que tiene mucho de profeta. Se siente llamado a un misión para con su época, a anunciar un mensaje profético: el eterno retorno de lo mismo, la transvaloración de los valores y el superhombre. Para comunicar estos mensajes liberadores Nietzsche utilizará a Zaratustra como heraldo

No nos podemos quedar sólo en la critica y denuncia que brota de la voluntad de vivir. En el seno de la voluntad de poder hay dos tipos de fuerzas: la activa y la reactiva. A partir de esta bipolaridad se define el proceso genealógico. Cada valor será referido a una u otra dirección del querer, se convierte en signo de un tipo u otro de instintos. De la voluntad de poder afirmativa nacen las fuerzas activas y de la voluntad de poder negativa, las fuerzas reactivas. Por ello unos valores son síntomas de un conjunto de instintos y fuerzas enfermas, en definitiva, de una voluntad de poder negativa 
y otros lo son de la vida y los instintos poderosos, signos de salud, de la voluntad de poder afirmativa.

Según predominen las fuerzas activas o reactivas nos encontraremos con diferentes nihilismos. Existe un nihilismo negativo, preparado por la ratio socrática y su despliegue platónico y consumado en y por el cristianismo, en el que "al no ser situado el centro de la vida en la vida, sino en el más allá, en la nada, se priva a la vida de un centro de gravedad". Este nihilismo significa la depreciación de la vida. La vida toma un valor de nada. Existe, asimismo, un nihilismo reactivo o pasivo, que rechaza el fundamento divino, trascendente de la realidad y se opone a las cosas "en sí". El hombre reacciona contra Dios y asume el lugar y la función del Dios "muerto". Este nihilismo reacciona contra ese mundo divino de valores superiores. Pero esta desvalorización de los valores superiores que pretenden negar la vida es en realidad la proclamación de la nada de los valores.

Pero existe también un nihilismo activo, que proviene de la voluntad de poder afirmativa, que es "signo de fuerza", de la fuerza de un espíritu tan acrecentado, que sus objetivos anteriores ("convicciones"67, artículos de fe, etc.) vienen a resultarle inadecuadas. Este signo de fuerza debe ser creativo y responder a los valores que apuestan por la vida. Este nihilismo activo es propio del superhombre, que, aunque se instala en la insensatez de mundo, está dispuesto a crear nuevos valores.

Estos nuevos valores que provienen de la voluntad de poder afirmativa son la transvaloración de los valores. Esos valores nuevos no podrán ser tomados del "supramundo" metafísico de donde han surgido los valores morales que ahora se están hundiendo definitivamente; han de ser valores meramente naturales. Valores que sean útiles para la vida, para el desarrollo de las fuerzas de la naturaleza humana. Lo único verdadero es la vida, que no tiene otro fundamento que ella misma y constituye la instancia última de todo. La vida se explica como voluntad de poder68; pues desde los seres inorgánicos hasta las formas más elevadas del espíritu humano todo es metamorfosis y expresión de la voluntad de vivir. Aspirar y tender a más y más poder, a más y más vida, éste es el absoluto de Nietzsche.

Dicha transvaloración permitirá acabar con la consideración platónicocristiana del mundo, con esa "mentira del orden moral del mundo". La transvaloración debe, en efecto, asumirse más bien como una inversión del punto de partida: de la negación originaria de la vida de la que surge la

67. Nietzsche, F., Más allá del bien, (259), 222. Véase también Genealogía, II (12), 90. 68. Ibid. 
interpretación platónico-cristiana de ésta y de su sentido, a su afirmación genuina, originaria. Bajo su poderosa luz, la venganza, el resentimiento y la debilidad dejarán de ser criterio de valores y de la verdad. La transvaloración conlleva una redefinición de lo bueno y de lo malo. Pero no en el sentido de una propuesta de valores nuevos que ocupen el lugar de los viejos, sino el de las virtudes o valores afirmativos de lo individual-vital. Valores vacíos, pues, de todo posible carácter absoluto y de toda pretensión universalista, genuina, siempre en el bien entendido, claro es, de que es bueno cuanto eleva el sentimiento de poder, malo cuanto procede de la debilidad69.

La voluntad de poder responde a un imperativo: ser más. Es un ímpetu o impulso, esencia de todo lo que existe, que siempre va "más allá", que busca crecer y desarrollarse. Este movimiento expresa la participación de todo en el devenir, en el movimiento que, como ya afirmara Heráclito, constituye la esencia de toda la realidad. Pero este impulso o movimiento puede orientarse hacia el aumento y la superación o hacia la declinación y degeneración.

Todo está para Nietzsche al servicio de la vida. No hay mirada directa alguna sobre la vida, en el sentido de venir libre de todo trasfondo y presupuesto. Todo lo que ocurre en ésta, incluida, por tanto, toda determinación teorética, sirve a la vida de un modo indeterminable, porque la vida no se ofrece globalmente como un todo. No hay otro patrón o criterio a tenor del que medir o sopesar la vida, que la vida misma, vida que es voluntad de poder, como lo es también el mundo, ese mundo dionisíaco de Nietzsche "que se crea a sí mismo eternamente y eternamente a sí mismo se destruye".

La vida es también "eterno retorno", "la cumbre de la reflexión", esto es, la existencia tal cual es sin sentido y finalidad, sino inevitablemente retornando, sin un término final en la nada. Un mundo no creado por un Dios ajeno, sino divinamente perfecto, autosuficiente, por sí mismo permanente desde siempre y para siempre incesantemente haciéndose y pereciendo, sin por qué ni para qué, sin razón ni sentido más allá de sí mismo. Nietzsche quería restaurar una visión griega, presocrática, del mundo, en oposición con la judeocristiana que considera el tiempo jalonado por momentos irrepetibles: creación, pecado, redención, fin de los tiempos... Nietzsche con el eterno retorno quiere decir que sólo en un mundo que ya no se pensara en el marco de una temporalidad lineal sería posible la felici-

69. MuÑoz, J., Nihilismo y la critica de la religión en Nietzsche, en Frauó, M., (ed.,) Filosofía de la religión, Trotta, Madrid 1994, 345-359. 
dad plena, al pensar que cada instante de nuestra vida se hiciera eterno y se repitiera hasta el infinito. La temporalidad lineal, la que se articula en el presente-pasado-futuro, cada uno de ellos irrepetible, cada momento tiene sentido sólo en función de los otros en la línea del tiempo. En esta concepción lineal del tiempo no es posible la felicidad porque ningún momento vivido puede tener, de veras, en sí, una plenitud de sentido.

Pienso que la temporalidad lineal no es la única manera de entender el tiempo dentro del cristianismo. Creo que se puede dar una interpretación cristiana circular del tiempo. Por ejemplo, el entender el año litúrgico en el que aparecen los momentos de la historia de la salvación, como algo que vamos viviendo cada año y como algo que vuelve a revivirse y a repetirse cada año. Dios también se puede entender dentro de esta circulación eterna, en el movimiento eterno de las horas, un Dios que está siempre en movimiento, una divinidad que está siempre en proceso, que está siempre siendo.

Para esta transvaloración de los valores y el eterno retorno se requerirá un tipo nuevo: el superhombre, el hombre nuevo, un hombre capaz de crear al fin, desde un pathos afirmativo y libre de resentimiento, nuevos valores, valores afirmativos e inmanentes a la vida. Lo que equivaldrá al desciframiento del sentido de nuestro ser. El superhombre es quien ha superado su naturaleza animal, se ha disciplinado y se ha creado a sí mismo. Ha llegado a ser un hombre tolerante, no débil sino fuerte, un espíritu que ha llegado a ser libre. El superhombre será "el sentido de la Tierra". El sentido que brotará del sin sentido al que nos ha abocado la historia entera de Europa en cuanto historia del despliegue -y consumación actual- del nihilismo, y redimirá, exculpando la culpa, la propia redención. El superhombre es un espíritu creador, un hombre redentor que anuncia y trae la "gran salud", liberándonos de la voluntad de nada, del nihilismo.

El superhombre es el hombre que no sigue la moral del rebaño, sino la vida libre y puede abrirse a nuevas posibilidades. El hombre que se supera a sí mismo, que se atreve a ser lo que es. El superhombre es el sentido de la vida y del mundo: la superación y la transfiguración de la existencia. Ahora bien, el superhombre está más allá de la felicidad como bienestar, es decir, ha descubierto que el sufrimiento pertenece a la vida y forma parte de la sabiduría de la vida.

El superhombre representa al Nietzsche positivo, el hombre del espíritu libre ${ }^{70}$ que afirma la vida con todas sus fuerzas. Es el que apuesta por la

70. SAFRANSKI, R., Nietzsche, 291-291. El superhombre es el hombre prometeico, que ha descubierto sus talentos teogónicos. El Dios fuera de él está muerto; pero está vivo el Dios del que sabemos que vive solamente a través del hombre y en el hombre; este Dios es 
posibilidad eficaz de la virtud humana. El superhombre es quien se mueve por la moral de señores y los valores aristocráticos. Por eso Nietzsche valora en él el ímpetu heroico, la mesura renacentista, la alegría de vivir, la fuerza vital, la humanitas. Es el hombre que cuando todo se ensombrecía y se desmoralizaba, supo confiar en la potencia amable de la vida y supo instaurar el sentido y el dominio sobre la tierra. Es el héroe que se compromete con la vida y ayuda a que el hombre recupere su propia naturaleza.

El superhombre es el hombre nuevo, es una nueva creación que supera al hombre viejo. Es un hombre animado por todas las fuerzas activas, por la voluntad de la afirmación, que está más allá de las posibilidades y aún de los sueños de la carne. Es el hombre que vive en la alegría y es capaz de danzar y jugar en la confianza de la existencia, en la afirmación de la inocencia del devenir-activo.

En el superhombre y en Zaratustra, profeta portavoz de la vida y del nihilismo activo, podemos ver una relación con el cristianismo, con el hombre nuevo que prepara la humanidad nueva. El mensaje de Zaratustra encaja con el cristianismo que apuesta por la vida en la fidelidad a lo real, en el compromiso con el mundo, en la liberación de las situaciones injustas. El cristiano, de esto modo, es el hombre erguido sobre el mundo, sobre la vida.

Por otra parte, la afirmación de la vida libre, plena, confiada y feliz es una constante del mensaje de Jesús, la formulación positiva de la amonestación constante. “¡No tengáis miedo!”. Los lirios del campo, los pájaros del cielo no siembran, ni siegan... Aprended de ellos a amar la vida plena, a vivir derechamente, a mirar con rectitud y alegría (Lc 12,22-31). La vida de Jesús no es reactiva, ni lo es tampoco la vida a la que él llama. La fe que pide el Padre de Jesús, no es sometimiento disfrazado, sino de confianza y fuerza; se trata de afirmación de la vida y del hombre. Jesús no enseña a morir, enseña a vivir venciendo el miedo a la muerte. Jesús propone nacer a una nueva vida, una vida activa.

Zaratustra ama, en efecto, a "quienes no necesitan buscar una razón para perecer y sacrificarse más allá de las estrellas, sino que se inmolan a la Tierra ${ }^{71 "}$. Esto es, a quienes saben, como en cierto modo sabemos ya nosotros, que ni la humanidad en su conjunto persigue fin alguno, $y$, a la vez, se entregan como el niño a sus juegos con feliz inocencia, definiendo al hacerlo su voluntad de ser ellos mismos.

un nombre para designar el poder creador del hombre. Este superhombre, después de la muerte de Dios, es el hombre que ya no tiene que hacer rodeos a través de Dios para poder creer en sí mismo.

71. NiETZSCHE, F., Thus spoke Zarathustra, 44. 
Deleuze 72 tiene razón: Nietzsche era enemigo de todas las fuerzas reactivas (mala conciencia, resentimiento). Soñó con un mundo en el que fuese posible desear el eterno retorno de lo igual. Todos sabemos que sucumbió en su empresa. Tal vez su metafísica trágica le condujo a la locura. No sabemos si fue o no el último metafísico de occidente, pero lo que sí es cierto, es que nadie ha intentado nunca una revolución de tanto alcance como la suya. $Y$ tampoco parece que nadie le haya igualado nunca en fuerza visionaria. Buena prueba de ello es que, más de un siglo después de su muerte, nos hallamos plenamente envueltos en la crisis que él predijo, en la crisis de la modernidad.

Como hemos venido explicando, en Jesús de Nazaret, en Pablo y en el cristianismo no hay mala conciencia ni resentimiento, sino un mensaje alegre, una apuesta por la vida. El mensaje del Reino se presenta una alegre nueva y no como amenaza. Una noticia alegre para todos. El Reino es buena noticia, apreciación de la vida, y para percibirlo así es necesario enderezar el alma y la mirada, mirar limpiamente al mundo. La alegría no se puede percibir ni sentir desde la culpabilidad ni desde el resentimiento. La afirmación del valor de la vida no se puede pronunciar desde el "no" dicho a lo otro. La vida y alegría de Dios es la vida del hombre, la plenitud del hombre. De cada hombre, único e irrepetible. La causa de Dios es la causa de los pobres, es la causa de la justicia. La gloria y alegría de Dios es que el ser humano sea ser humano. Es decir, toda afirmación de Dios que no va unida a su afirmación practica: trabajar por la justicia, es una idolatría y por lo tanto, una negación de Dios.

Creo que, interpretado de este modo, se puede encontrar cierta similitud entre el mensaje cristiano y el de Nietzsche. Y, aunque estemos en el siglo XXI, se puede seguir afirmando con Nietzsche que "el cristianismo auténtico, el originario será posible en todos los tiempos". Por eso, a parte de la crítica radical que Nietzsche hace al cristianismo, y conforme a la que continuamente tendremos que revisar nuestra vida cristiana, también se puede hacer un acercamiento válido al Dios de Jesucristo, al Dios de la vida y del amor, que quiere una vida digna para todos los hombres.

El mensaje de Nietzsche no sólo es un ataque virulento contra el cristianismo; también lo libera de toda valoración antivital, de la despreocupación por la vida y de poner el centro de gravedad en el más allá.

JAVIER ANTOLÍN SÁNCHEZ Estudio Teológico Agustiniano

Valladolid 